\title{
DISCOURSE ON TELEVISION TALK SHOWS: GENRE OR FORMAT
}

Summary: Different approaches to the analysis of television production - one-dimensional and multi-dimensional, exist. All television products are classified by purpose, format, way, and frequency of display, audience, genre, country of production, by who it was produced - the channel itself, or a third-party production company, whether this project is licensed or original. In recent years, Russian TV channels have been broadcasting a large number of conversational TV programs - talk shows. In the programmed broadcasting schedule of some TV channels, they take about 9 hours of airtime, and this is without repetitions. These projects can also be classified in several directions.

A discussion between people on a particular topic, which includes elements of such genres as interviews and conversation, is the main essence of a talk show. The debate is a recognized genre of analytical journalism, but at the same time, many talk shows are also defined as a genre. The theory of genre is one of the most significant theoretical development areas in art history, but no single, generally accepted definition exists.

Some people believe that the tasks of modern talk shows are well known. This is primarily a desire to make

Talk shows are primarily conversational TV projects - a TV show in the form of a free exchange of views on a given topic, during which the guests (experts) answer the host, guests, and present viewers' questions. It is a kind of a triangle: a presenter - an expert - the studio's audience. It is believed that the first such programs appeared on Russian television in the late eighties. However, they were aired under the name "Teleconference Leningrad - Boston", "Teleconference MoscowCalifornia", "Teleconference Moscow - San Francisco", and others. Vladimir Pozner was the presenter from the USSR, from the USA - Phil a comprehensively exciting television program with elements of intrigue from a primitive topic, to attract attention and a desire to form a specific attitude to the problem under discussion. The author has a different opinion on some points.

Indeed, any show is based on attracting attention. For such projects, the presence of viewers in the studio became a kind of confirmation of the audience's interest in the topic and the opportunity to include them in the discussion, to achieve social commonality.

However, from the author's point of view, greater attention must be paid to the idea what the producer wants to convey to the audience and how he wants to see it in the future, to the content - with what information and in what genre to do the project, and to the understanding in what form/format to make the content.

At the same time, it is essential to remember that according to the theory of V.Behterev, the process of making people have a specific emotional state occurs faster and more efficiently than an attempt to convince them with the help of logical reasoning.

Keywords: classification, talk show, discussion, genre, format, purpose.

Donahue, a journalist thanks to whom such a format as talk show appeared on television in the sixties ("The Phil Donahue Show" (WDTN) in Dayton, aired from 1967 to 1996, 6000 releases). Phil Donahue initially invited one guest to the studio. In the case of controversial issues, supporters of different points of view came; however, not immediately but separately and on different days, which was done to avoid heated arguments between the participants. Donahue conducted live interviews with experts, inviting viewers to call the studio. The program gradually changed. Over time the presenter left his chair and went out with 
a microphone into the auditorium, allowing the viewer to ask the guest questions. The opinion of the ordinary viewer, introduced to the talk show, is considered the merit of Phil Donahue. According to the press release: "Donahue's widely popular US program is broadcast five times a week and specializes in controversial or informative topics and meetings with interesting people. For each of his programs, which lasts exactly an hour, Donahue chooses only one topic or one person but illuminates them vividly and in many ways... Directly from their seats, viewers ask the guests questions, comment on their opinions, speak with their own and sometimes argue with each other, which gives the program a spontaneous character and makes it diverse... The acute polemic programs provide viewers with new information and, at the same time, entertain them" [1].

In the early sixties, talk shows, as a spoken performance, appeared on the USSR Central Television. You can recall the weekly program "Blue Light" ("Television Cafe", "At the Blue Light" are the original names), which went on weekly television screens for many years; now, it is associated only with New Year's releases. Well-known cultural figures and production leaders took part in the program. The hosts introduced the guests, interviewed them, actors, singers performed. Both conversation and performance were present there. The author of the article also remembers a video recording of a literary program from the Teleradiofond in which Irakli Luarsabovich Andronnikov as a presenter communicates with the audience at Shabolovka studio. Andronnikov was a writer, literary critic but at the same time an amazing master of artistic storytelling, artistic, with a great sense of humor, often parodying famous people (you can recall the recording of his speech "First Time on the Stage"). However, much is forgotten, English words in the sixties were not so in fashion, and the teleconferences held in the late eighties began to be considered the beginning of the era of talk shows on Russian television. In the late eighties and nineties, a search for new forms of presenting television material was acute, and democratic changes also impacted society. What was discussed in the kitchens was transferred to television screens (the first attempts were in the program of the youth editorial office "Vzglyad").
This excursion into history is since talk shows have become, one might say, one of the most popular formats on modern Russian television. If we calculate the time taken today by such projects on the air, then on Channel One, it is 8 hours 40 minutes a day on weekdays, on Russia1 - 8 hours, on NTV - 3 hours (in the premiere version). Talk shows are aired in the morning, afternoon and evening, and are repeated at night.

In textbooks for journalists, it is noted that talk shows are a genre, and this genre is presented in the section "Journalism Television Genres" [2, p.195]. Theorists of television journalism understand genre as a historically defined type of reflection of reality, which has several relatively stable features [2, p.170]. Information genres and genres of analytical journalism are distinguished.

Television production, which includes talk shows, can be classified according to several directions: by purpose, format, frequency, method, and time of showing, by the audience, by genre, by whether it is its production or not. That is, who produced it, the channel itself, or a production company with the subsequent sale to the channel and the country of production. The division of talk shows takes place according to the purpose; it is entertaining/socially activating/developing, according to topics, according to the method and airing time - live broadcast or recording, morning/ afternoon/evening, even according to gender. The projects of the First Channel - "Evening Urgant", "Tonight" can be classified as entertainment projects; "Time Will Tell" or "60 minutes" on channel Russia 1 are socially activating ones. If we consider topics, the project "Evening with Vladimir Solovyov" was dedicated only to Ukraine for a long time. In the spring of 2020, COVID 19 was the topic of discussion of almost all issues. The first women's talk show "Me" was aired on TV-6, "City of Women" on the First Channel, "What a Woman Wants" on Russia 1, "Maiden Tears" on TNT. The men's talk show "Only for Men" is on channel TV Center, and the talk show "Male / Female" is on the First Channel nowadays.

The main essence of a talk show is that it is a discussion between people on a particular topic, including such genres as interviews and conversation. It is a recognized genre of analytical journalism: "The clash of different opinions includes the TV audience in the research process, activating intellectual activity, overcoming the 
passivity characteristic of the perception of readymade truths. Hence the high cognitive potential of the genre" [2, p.195]. Today, the question of the cognition of this genre is very controversial. In one of the broadcasts of the project "The Glass Bead Game" on channel Russia K, the topic of whether Gianni Rodari's "Adventure of Cipollino" could be attributed to the genre of a social fairy tale was discussed. On channel Russia 1 on-air "Andrey Malakhov. Live", the theme was Lena Lenina's wedding plan "Mom is Against!". For those who do not know, the heroine of the program is a shocking businesswoman, known for her extravagant hairstyles, she cut her hair and got married.

The Glass Bead Game project is named after the novel of the same name by Hermann Hesse, in which there is a group of intellectuals in the center of the story; the same group is gathered in a television studio. "About 'The Glass Bead Game' project with Igor Volgin. A talk show. In the studio, four heroes, among whom there are philosophers, critics, writers, actors, and directors, are discussing current works of world literature" [3]. "Talk Show 'Andrey Malakhov. Live' is a real chronicle of our life. It is a program about each of us: about what worries us and how the country lives. The loudest journalistic investigations, topical events, sensations from the world of stars, and people who need our help are every day on weekdays in the studio 'Live'". [4] It is rather difficult to assume that the topic mentioned above of Malakhov's program is the one that worries many and activates intellectual activity. If we compare these two projects, characterized by the producer as a talk show, then, as it seems, we can speak about cognition only concerning the first one. Of course, one could argue that these programs have different audiences. Russia $\mathrm{K}$ is watched by men and women from 25 to 59 years old, with higher education, interested in world culture and art. The target audience of Russia 1 is most of the country's population; these are men and women (who prevail) over 18 years old, (65+ group - 40\%, 55-64 - 24\%, 40-54 -21\%, 25 $-11 \%, 16-24-39 \%$ ) [5]. However, based on these data, the main difference lies in the interests of the audience, the topic, the intensity of the discussion, and the fact that the "Glass Bead Game" is more about a conversation, an exchange of opinions. And it is not necessary to turn all TV programs into a show, in this case, discussion one.
Of course, each genre is a historical phenomenon, changing, leaving the living process of art and sometimes returning to life, more often in a transformed form. [6]

Life is changing, and people are changing, their attitude to life is changing. The COVID 19 pandemic displaced many of the news feeds' topics when the eternal question of life and death began to arise, affecting almost everyone in the world. Forgetting about how the bulk of the country's population lives - most often in cramped living conditions, the way the "stars" spend their time on self-isolation in their properties near Moscow was shown, according to the old habit, in many television programs, first of all in Malakhov's, in the first weeks... It is the direction of thinking of the creators of the project. And only after the experts, invited to the program, paid attention to this, such materials began to "disappear" from releases. The experts changed; numerous women pregnant from "stars", mistresses of mayors, pensioners waiting for a child from their former sons-in-law were replaced by academicians, professors, doctors, artists, volunteers. The rhetoric, the style of discussion, behavior, and dress changed. It must be admitted that both approaches are a real reflection of reality, it is vital which one of them the producers and editors would highlight. Will the plot, thematic content, and style of the TV project change in the future, or will the rating and commercial benefit win? Viewers accustomed to "yellowness" are not accustomed to the severe presentation of material. Only the broadcast dedicated to the next contrived scandal with the former TV presenter Dana Borisova entered the hundreds of rating programs of April 2020.

The tasks of modern talk shows are known. First of all, this is a desire to make a comprehensively exciting program with elements of intrigue from a primitive topic, attract attention, and form a specific attitude to the issue under discussion, an attempt to find individual solutions to a particular problem. [7] The statement "primitive" is debatable since the theme of the "Glass Bead Game" can hardly be called primitive, and it, as noted above, is defined by the producers as a talk show.

Any show is based on attracting attention. The presence of viewers in the studio became a kind of confirmation of the audience's interest in the topic and the ability to include them in the discussion, to achieve social community. Russian 
TV producers and editors adopted this Western form of presentation; however, it has not fully worked. Extras are mostly passive, and occasional shouts or statements look foreign. Only in the project "Cultural Revolution" (channel RussiaK), viewers were organically included in the discussion process. It was because they were part of the target audience, not random extras. The speakers understood what was being discussed, and their questions were included in the conceptual outline of the project. The television program "School of Scandal" had been aired for twelve years. The creators also described it as a talk show. From the point of view of the author, the project came out in the genre of conversation. The presenters, Tatyana Tolstaya and Avdotya Smirnova, talked in the studio with the guest. With the transition from one channel to another, the "School of Scandal" changed, in which silent viewers/extras appeared, then disappeared again. However, this did not affect the essence of the program in any way. In the daytime talk show "The City of Women" (2003-2004, Channel One), they used live calls, as did Phil Donahue. However, over time, this was discontinued since not everyone can clearly and concisely formulate a question, and it happened that the callers did not deny themselves the pleasure of hooliganism. Some channels used interactive voting of viewers in the studio - "Freedom of Speech" (2001-2004, NTV), "Fashionable Sentence" (2007 to this day, Channel One), or "A Duel" (2010-2017, Russia1) where viewers participated in the program by voting for the position of the speaker of their choice using phone calls and SMS messages. As an element of interest in the topic under discussion, the results of the audience voting were shown live. A socio-political informative and debate television program on channel NTV, "The Place of Meeting", is broadcast in the usual format with viewers (without them during the period of "self-isolation") who in no way take part in what is happening in the studio. However, sound engineers periodically broadcast pre-recorded breaths, ahs, laughter, and applause of this crowd, as proof of the active perception of the content. Nevertheless, it looks artificial since television directors often brought out this sound in general plans, and then it was clear that the studio audience did not react in reality. Such a method came to our screens from the American channel CBS, on which sound engineer Charlie Douglas was the first to introduce offscreen laughter as a reaction. It was used in American sitcoms of the past years, which were broadcast live, and the audience reacted to what was happening. With the transfer of filming to the studio, the offscreen laughter was kept. It is a kind of emotional impact and a guide to a reaction.

However, from the author's point of view, more attention should be paid to the concept - what the producer wants to convey to the audience, and what he wants to see in the future, to the content - what information to fill in and in what genre (in the case of talk shows, three criteria are taken into account when determining the topic: public interest, discussion, the competence of the audience-participant), and to understanding in what form/format this content should be made. This leads to specific features of a talk show: live broadcast, or recorded; shooting in the studio; one or more presenters; guests, preferably celebrities; entertainment elements of the show; the audience in the studio; serial releases. It seems that live broadcast is preferable; firstly, it is regulated in time, the audience does not get tired, and secondly, it gives liveliness and poignancy. With today's production organization, some talk shows are recorded four episodes per shift. Each channel has its guests/celebrities, and if we talk about guests/experts of social and political shows, they, as they say, move from studio to studio, spending the whole day on television. As for entertaining show elements, this often refers to scandals and an invitation of freak guests, or performances of "show stars".

At the same time, we must bear in mind that according to the social and psychological theory of V.Bekhterev, who interpreted the processes of communication and the mutual psychological influence of people on each other as a mechanism of socialization, the process of making people have a specific emotional state occurs faster and more efficiently than an attempt to convince them with the help of logical reasoning [8, p.15]. And, here, the question arises, what topics evoke emotions in the audience. Thus, the "quality/competence" of the audience, both on TV screens and in the studio, must be considered.

Different attitudes towards the format exist; on the one hand, it is characterized as a general concept of a TV program, acting as a brand; on the other hand, speaking of the format, it means 
a license to produce and broadcast a finished foreign version of a television project. Some people believe that a format is a system of agreements with the viewer of each program. It is what makes it unique, unlike others, and similar to itself in each episode. English producer Charlotte Worthington, for example, identifies the following types of formats:

- a talk show, usually hosted by a famous person;

- music programs, these are concert broadcasts and music videos;

- sports programs - broadcasts of sports events and entertainment shows;

- news;

- reality show;

- game shows [9, p.132].
In the case of modern Russian talk shows, the structure is almost always the same, and the channels determine the characteristics of the content presentation based on their audience. Differences are in what the TV channels aim at. Marketing/demand management may require more serious consideration.

Conclusion: the genre is rather semantic characteristics, and the format determines the production characteristics - the structure, the content, specific features, the adaptation (for licensed projects), the style, the packaging, the cost, the production, and distribution method. That is, the format is the form in which the content is expressed.

\section{REFERENCES}

1. Kuznetsov, G.V. 2004. This is How TV Journalists Work, Moscow

2. Television Journalism. Moscow 2005

3. Based on materials from URL: https: //tvkultura.ru

4. Based on materials from URL: https: //russia.tv

5. Based on materials from URL: www.brandmedia.ru

6. Shergova, K.A. 2016. Formation of the Genres of Documentary Television, Moscow, p.7.
7. Gorshkova, E.F., Futerman E.B. The Feasibility of Using the Talk Show Format on Modern Television.

8. Matveeva, L.V., Anikeeva, T.Y., Mochalova, Y.V. 2020. Psychology of Television Communication. Moscow,

9. Worthington, C. 2010. Basics Film-Making 01: Producing. AVA Publishing,. p.132. 


\section{РАССУЖДЕНИЯ НА ТЕМУ ТОК-ШОУ: ЖАНР ИЛИ ФОРМАТ}

\begin{abstract}
Аннотация: Существуют разные подходы к анализу телепродукции - одномерные и многомерные. Вся телевизионная продукция классифицируется по назначению, формату, по способу и частоте показа, аудитории, жанру, стране производства, по тому, кто ее производил - сам канал или сторонняя продюсерская компания, лицензионный ли этот проект или оригинальный. В последние время российские телеканалы ставят в эфир большое количество разговорных телепередач - ток-шоу. В программной сетке вещания некоторых телеканалов они занимают около 9 часов эфирного времени и это без повторов. Классифицировать эти проекты также можно по нескольким направлениям.

Основная суть ток-шоу в том, что это дискуссия между людьми на определенную тему, включающая в себя элементы таких жанров, как интервью, беседа. Дискуссия - признанный жанр аналитической публицистики, но при этом многие ток-шоу также определяют как жанр. Теория жанра - одна из наиболее значимых областей теоретической разработки в искусствоведении, но единого, общепринятого определения не существует.

Некоторые считают, что задачи современных токшоу известны, это в первую очередь желание из
\end{abstract}

Ток-шоу, это в первую очередь разговорные телепроекты (англ. talk - говорить, show - показ, что соответствует природе телевидения) - телепередача в виде свободного обмена мнениями на заданную тему, в ходе которой приглашенные гости (эксперты), отвечают на вопросы ведущего, присутствующих гостей и телезрителей. Своеобразный треугольник ведущий - эксперты - зрители в студии. Считается, что первые такие программы на российском телевидении появились в конце восьмидесятых, правда выходили они в эфир под названием «Телемост Ленинград примитивной темы сделать всесторонне интересную телевизионную передачу с элементами интриги, привлечение внимания и желание сформировать конкретное отношение к обсуждаемой теме. По некоторым позициям автор имеет другое мнение.

Действительно, любое шоу основывается на привлечении внимания, и наличие зрителей в студии для таких проектов стало своеобразным подтверждением интереса аудитории к теме и возможностью включать их в дискуссию, достичь социальной общности.

Но, с точки зрения автора, большее внимание необходимо уделять замыслу, тому, что производитель хочет донести до аудитории и какой он хочет ее видеть в будущем, содержанию, какой информацией и в каком жанре наполнить проект, и пониманию того, в какую форму/формат, это содержание облачить.

При этом важно помнить, что по теории В.М. Бехтерева заражение людей определенным эмоциональным состоянием происходит быстрее и эффективнее, чем попытка убедить их с помощью логических умозаключений.

Ключевые слова: классификация, ток-шоу, дискуссия, жанр, формат, назначение.

- Бостон», «Телемост Москва - Калифорния», «Телемост Москва - Сан-Франциско» и другие. Ведущим со стороны СССР был Владимир Познер, с американской - Фил Донахью, журналист, благодаря которому в шестидесятые годы на телевидении появился такой формат, как ток-шоу (The Fil Donahue Show - «Шоу Фила Донахью» (WDTN) в Дейтоне, выходило с 1967 по 1996 год, 6000 выпусков). Первоначально Фил Донахью приглашал в студию одного гостя. В случае спорных вопросов приходили сторонники разных точек зрения, но не сразу, а по отдельности и в 
разные дни, что делалось во избежание перепалок между участниками. Донахью в прямом эфире вел интервью с экспертами, предлагая зрителям звонить в студию. Постепенно передача менялась, со временем ведущий покинул свое кресло и вышел с микрофоном в зрительный зал, дав возможность зрительнице задать вопрос гостю. Мнение обыкновенного зрителя, введенного в ток-шоу, считается заслугой именно Фила Донахью. Из пресс-релиза: «Пользующаяся в США широкой популярностью программа Донахью передается пять раз в неделю и специализируется на спорных или информативных темах и встречах с интересными людьми. Для каждой своей передачи, которая длится ровно час, Донахью выбирает только одну тему или одного человека, но освещает их живо и разносторонне... Зрители прямо с мест задают свои вопросы гостям, комментируют их мнения, выступают с собственными и подчас спорят друг с другом, что придает программе спонтанный характер и делает ее разнообразной... Острополемические программы дают зрителю новую информацию и одновременно развлекают его» [1].

В начале шестидесятых годов ток-шоу как разговорное представление появилось и на Центральном телевидении СССР. Можно вспомнить еженедельную передачу «Голубой огонек» (первоначальные названия «Телевизионное кафе», «На голубой огонек»), которая долгие годы еженедельно выходила на телеэкраны, это сейчас она ассоциируется только с новогодними выпусками. В передаче принимали участие известные деятели культуры, передовики производства. Ведущие представляли гостей, брали у них интервью, актеры, певцы выступали с концертными номерами. В них присутствовал и разговор, и представление. Автор статьи также помнит видеозапись литературной программы из Телерадиофонда, где Ираклий Луарсабович Андроников в качестве ведущего общается со зрителями в студии на Шаболовке. И.Л. Андроников был писателем, литературоведом, и при этом потрясающим мастером художественного рассказа, артистичным, с великолепным чувством юмора, часто пародирующим известных людей (можно вспомнить запись его выступления «Первый раз на эстраде»). Но многое забывается, англоязычные слова в шестидесятые были не особенно в моде и проведенные в конце восьмидесятых годов телемосты стали считать началом эры ток-шоу на российском телевидении. В конце восьмидесятых и в девяностые годы остро стоял вопрос поиска новых форм подачи телематериала, влияние оказали и демократические изменения в обществе. То, о чем говорили на кухнях, перенесли на телеэкраны (первые попытки были в передаче молодежной редакции «Взгляд»).

Этот экскурс в историю связан с тем, что токшоу стало, можно сказать, одним из самых популярных форматов на современном российском телевидении. Если подсчитать время, занимаемое сегодня в эфире такими проектами, то на Первом канале оно составляет 8 часов 40 минут в день по будням, на России 1 - 8 часов, на НТВ - 3 часа (в премьерном варианте). Ток-шоу выходят в эфир в утреннее, дневное и в вечернее время, с повтором ночью.

В учебниках для журналистов отмечают, что ток-шоу - это жанр и представлен он в разделе «Телевизионные жанры журналистики» [2, с. 195]. Теоретики телевизионной журналистики под жанром понимают исторически определившийся тип отображения реальной действительности, обладающий рядом относительно устойчивых признаков [2, с. 170]. Выделяют информационные жанры и жанры аналитической публицистики.

Телевизионная продукция, к которым относится и ток-шоу, может классифицироваться по нескольким направлениям: по назначению, формату, по периодичности, способу и времени показа, по аудитории, по жанру, по тому, собственное это производство или нет. То есть кто ее производил - сам канал или продюсерско-производственная компания с последующей продажей каналу, а также по стране производства. Деление ток-шоу происходит по назначению, это - развлекательное/социально-активизирующее/ развивающее, по темам, по способу и времени выхода в эфир - прямой эфир или запись, утреннее/дневное/вечерние, даже по гендерному принципу. К развлекательным можно отнести проекты Первого канала - «Вечерний Ургант», «Сегодня вечером», к социально-активизирующим - «Время покажет» или «60 минут» на канале Россия1. Если говорить о теме, то проект «Вечер с Владимиром Соловьевым» долгое время посвящался только Украине. Весной 2020 г. темой обсуждения практически всех выпусков был Covid 19. Первое женское ток-шоу «я сама» выходило в эфир на телеканале «ТВ-6», «Город женщин» на Первом, «Что хочет женщина» на 
России 1, «Девичьи слезы» на ТНТ. Мужское ток-шоу «Только для мужчин» на телеканале ТВ Центр, сейчас на Первом канале выходит ток-шоу «Мужское/Женское».

Основная суть ток-шоу в том, что это дискуссия между людьми на определенную тему, включающая в себя элементы таких жанров, как интервью, беседа. Это признанный жанр аналитической публицистики - «Столкновение различных мнений включает телеаудиторию в процесс исследования, активизируя интеллектуальную деятельность, преодолевая пассивность, характерную для восприятия готовых истин. Отсюда высокий познавательный потенциал жанра» [2, с. 195]. Вопрос познавательности этого жанра на сегодняшний день весьма спорный. В одном из эфиров проекта «Игра в бисер» на канале Россия К, обсуждали тему, можно ли «Приключение Чиполлино» Джанни Родари отнести к жанру социальная сказка. На канале Россия 1 в эфире «Андрей Малахов. Прямой эфир» тема - свадебный переполох Лены Лениной. Мама против! Для тех, кто не в курсе, героиня передачи - эпатажная бизнесвумен, известная своими экстравагантными прическами, остригла волосы и вышла замуж.

Проект «Игра в бисер», названа в честь одноименного романа Германа Гессе, в центре повествования которого, группа интеллектуалов, такую же группу собирают и в телевизионной студии. «О проекте «Игра в бисер» с Игорем Волгиным. Ток-шоу. В студии четверо героев, среди которых философы, критики, писатели, актеры и режиссеры, обсуждают актуальные произведения мировой литературы» [3]. «Токшоу «Андрей Малахов. «Прямой эфир»- настоящая хроника нашей жизни. Это программа о каждом из нас: о том, что нас волнует и чем живет страна. Ежедневно по будням в студии «Прямого эфира» самые громкие журналистские расследования, актуальные события, сенсации из мира звезд и люди, которым нужна наша помощь» [4]. Предположить, что указанная выше тема программы А. Малахова именно та, которая волнует многих и активизирует интеллектуальную деятельность, довольно сложно. Если сравнивать эти два проекта, охарактеризованные производителем как ток-шоу, то о познавательности, как представляется, можно говорить, только в отношении первого. Конечно, можно возразить, что у этих программ различная аудитории. У Россия К, это - мужчины и женщины от 25 до 59 лет, с высшим образованием, интересующиеся мировой культурой и искусством. Целевая аудитория России 1 - большая часть населения страны, это мужчины и женщины (которые превалируют) старше 18 лет (группа 65+ - 40\%, 55-64 - 24\%, 40-54-21\%, 25 лет -11\%, 16-24-39\%) [5]. Но, в принципе, исходя из этих данных, основное отличие - в интересах аудитории, теме, накале дискуссии и в том, что «Игра в бисер» больше относится к беседе, обмену мнениями. И совсем не обязательно все телепередачи превращать в шоу, в данном случае, разговорное.

Конечно, каждый жанр есть явление историческое, претерпевающее изменения, уходящее из живого процесса искусства и иногда возвращающееся к жизни, чаще в преобразованном виде [6].

Меняется жизнь, меняются люди, меняется их отношение к жизни. Пандемия Covid 19 вытеснила многие темы, которым были посвящены новостные ленты, когда начал вставать извечный вопрос жизни и смерти, коснувшийся практически всех в мире. В первые недели во многих телевизионных программах, в первую очередь у А. Малахова, по старой привычке показывали, как «звезды» проводят время на самоизоляции в своих подмосковных владениях, забывая о том, как живет основная масса населения страны, чаще в стесненных жилищных условиях. А это направленность мышления создателей проекта. И только после того, как приглашенные на программу эксперты, обратили на это внимание, такие материалы стали «уходить» из выпусков. Изменился состав экспертов, на смену многочисленным беременным от «звезд», любовницам мэров, пенсионеркам, ждущим ребенка от бывшего зятя, пришли академики, профессура, врачи, деятели искусства, волонтеры. Изменилась риторика, стиль дискуссии, поведения, одежды. Надо признать, что и тот, и другой подход - это реальное отображение действительности, важно, какой продюсеры и редакторы выдвинут на первый план. Изменится ли в дальнейшем сюжетное, тематическое наполнение и стиль телепроекта или рейтинг и коммерческая выгода победят. Зрители, приученные к «желтизне», не привыкли к серьезной подаче материала, и в сотню рейтинговых программ апреля 2020 г. вошел только эфир, посвященный очередному надуманному скандалу с бывшей телеведущей Даной Борисовой. 
Задачи современных ток-шоу известны, это в первую очередь желание из примитивной темы сделать всесторонне интересную программу с элементами интриги, привлечение внимания и желание сформировать конкретное отношение к обсуждаемой теме, попытка найти индивидуальные пути решения той или иной проблемы [7]. С утверждением «примитивной» хотелось бы поспорить, ведь вряд ли темы «Игры в бисер» можно назвать примитивными, а она, как отмечено выше, определяется производителями как ток-шоу.

Любое шоу основывается на привлечении внимания, и наличие зрителей в студии стало своеобразным подтверждением интереса аудитории к теме и возможностью включать их в дискуссию, достичь социальной общности. Российские телепродюсеры и редакторы переняли эту западную форму подачи, но полноценно она не работала и не работает. Массовка в основном пассивна, а редкие выкрики или высказывания смотрятся инородно. Только в проекте «Культурная революция» (канал Россия К) зрители были органично включены в процесс дискуссии. Это было связано с тем, что они были частью целевой аудитории, а не случайной массовкой. Выступающие понимали, о чем идет речь, и их вопросы были включены в смысловую канву проекта. В течение двенадцати лет выходила телевизионная передача «Школа злословия», также охарактеризованная создателями как ток-шоу. С точки зрения автора, проект выходил в жанре беседы. Ведущие, Татьяна Толстая и Авдотья Смирнова, беседовали в студии с приглашенным гостем. С переходом с одного канала на другой «Школа злословия» видоизменялась, в ней то появлялись безмолвные зрители/массовка, то опять исчезали. Но это никак не повлияло на суть программы. В дневном ток-шоу «Город женщин» (2003-2004 гг., Первый канал) использовали звонки в прямом эфире, как это делал и Фил Донахью, но со временем от этого отказались, так как умение кратко и четко формулировать вопрос есть не у всех, а бывало, что звонившие не отказывали себе в удовольствии похулиганить. На некоторых каналах использовали интерактивное голосование зрителей в студии - «Свобода слова» (2001-2004 гг., НТВ), «Модный приговор» (2007 г. - по сей день, Первый канал) или «Поединок» (2010-2017 гг., Россия1), где телезрители подключались к программе, голосуя за позицию выбранного ими спикера с помощью телефонных звонков и СМС-сообщений. Результаты зрительского голосования, как элемент заинтересованности в обсуждаемой теме, показывались в прямом эфире. Общественно-политическая информационно-дискуссионная телевизионная передача на канале НТВ «Место встречи» в обычном формате выходит со зрителями (в период «самоизоляции» без них), которые никак не принимают участия в происходящем в студии, но звукорежиссеры периодически выдают в эфир заранее записанные вдохи, ахи, смех и аплодисменты этой массовки, как доказательство активности восприятия содержания. Но, выглядит это искусственно, так как часто телевизионные режиссеры выводили этот звук на общих планах, где было видно, что студийная аудитория в реалии не реагирует. На наши экраны такой прием пришел с американского канала CBS, на котором звукорежиссером Чарли Дугласом впервые был введен как реакция - закадровый смех. Он использовался в американских ситкомах (комедия положений) прошлых лет, которые выходили в прямом эфире, и зрители, сидящие в зале, реагировали на происходящее. С переносом съемок в студию закадровый смех сохранили. Это своеобразное эмоциональное воздействие и ориентир на реакцию.

Но, с точки зрения автора, больше внимания необходимо уделять замыслу, тому, что производитель хочет донести до аудитории и какой он хочет ее видеть в будущем, содержанию, какой информацией наполнить и в каком жанре (в случае ток-шоу при определении темы учитывать три критерия: общественный интерес, дискуссионность, компетентность аудитории-соучастника) и пониманию того, в какую форму/формат это содержание облачить. Из этого вытекают специфические особенности ток-шоу: выход в прямом эфире или в записи; съемки в студии; один или несколько ведущих; гости, желательно знаменитости; развлекательные элементы шоу; зрительская аудитория в студии; серийность передачи. Как представляется, прямой эфир предпочтительнее, во-первых, регламентирован по времени, публика не устает, во-вторых, придает живость и остроту. При сегодняшней организации производства некоторые ток-шоу записывается по четыре выпуска в смену. Гости/знаменитости на каждом канале свои, а если говорить о гостях/ экспертах общественно-политических шоу, то они, как говорится, переходят из студии в студию, 
проводя целый день на телевидении. Что касается развлекательных шоу-элементов, то часто это относится к скандалам и к приглашенным - гостям-фрикам или выступлению «шоу-звезд».

При этом необходимо помнить, что по социально-психологической теории В.М. Бехтерева, который трактовал процессы общения и взаимного психологического влияния людей друг на друга как механизм социализации, заражение людей определенным эмоциональным состоянием происходит быстрее и эффективнее, чем попытка убедить их с помощью логических умозаключений [8, с. 15]. И тут встает вопрос, какие темы вызывают эмоции у аудитории. А на основании этого - задумываться о «качестве/ компетентности» аудитории, как у телеэкранов, так и в студии.

К формату относятся по-разному, с одной стороны, под ним подразумевают общую концепцию передачи, которая выступает в качестве бренда, с другой стороны, говоря о формате, подразумевают лицензию на производство и вещание готовой иностранной версии телевизионного проекта. Некоторые считают, что формат - это система договоренностей со зрителем каждой программы, это то, что делает ее уникальной, непохожей на других и похожей в каждом выпуске на себя. Английский продюсер Шарлотт
Вортингтон, к примеру, выделяет такие типы форматов:

- ток-шоу, которое как правило, ведет известный человек;

- музыкальные программы, это трансляции концертов и музыкальные клипы;

- спортивные программы - трансляции спортивных состязаний и развлекательные шоу;

- новости;

- реалити-шоу;

- игровые шоу [9, с. 132].

В случае современных российских ток-шоу структура практически всегда схожа, а каналы определяют для себя особенности подачи контента исходя из своей аудитории. Различия в том, какую цель ставят перед собой телеканалы. Возможно, необходимо серьезней задуматься над управлением маркетингом/ управлением спросом.

Вывод: жанр - это, скорее, смысловые характеристики, формат определяет производственные характеристики - структуру, содержание, специфические особенности, адаптацию (касается лицензионных проектов), стиль, упаковку, стоимость, способ производства и распространения. То есть формат - это та форма, в которую облекают содержание.

\section{БИБЛИОГРАФИЯ}

1. Кузнецов Г.В. Так работают журналисты ТВ. 2004

2. Телевизионная журналистика. Москва, 2005.

3. По материалам URL: https://tvkultura.ru.

4. По материалам URL: https://russia.tv/brand/show/ brand_id62142/.

5. По материалам URL: www.brandmedia.ru.

6. Шергова К.А. Становление жанров документального телекино. - М., 2016. - С. 7.

7. Горшкова Е.Ф., Футерман Е.Б. Целесообразность использования формата ток-шоу на современном телевидении..
8. Матвеева Л.В., Аникеева Т.Я., Мочалова Ю.В. Психология телевизионной коммуникации. - Москва, 2020.

9. Ch. Worthington. Basics Film-Making 01: Producing. AVA Publishing. - 2010. - 132 p. - URL: https://vuzlit. ru/316634/opredelenie_tipy_harakteristiki_ponyatiya_ format_teleprogrammy. - Ch. Worthington. Basics FilmMaking 01: Producing. AVA Publishing, 2010. - 132 p. 